\title{
The effect of iron stores on iron absorption in the rat: The possible role of circulating ferritin
}

\author{
J. GREENMAN AND A. JACOBS \\ From the Department of Haematology, Welsh National School of Medicine, Heath Park, Cardiff
}

SUMMARY Iron absorption in man is inversely related to body iron stores and serum ferritin concentration.

A negative correlation between intestinal iron absorption and the amount of storage iron in the body has been confirmed in the rat and the hypothesis that absorption may be regulated through the mediation of ferritin has been tested.

There was no difference in mucosal iron uptake or absorption between rats undergoing a jugular infusion of ferritin and those infused with saline despite a hundredfold difference in circulating ferritin concentration.

The intestinal absorption of iron is related to the amount of storage iron in the body. In man, absorption of iron is increased in iron deficiency and decreased when stores are excessive (Jacobs, 1973; Turnbull, 1974). The level of absorption may be affected by iron stores in the presence of normal haemoglobin, serum iron and transferrin concentrations (Pirzio-Biroli and Finch, 1960; Conrad and Crosby, 1962; Heinrich, 1970). These concentrations do not reflect iron stores directly and are therefore unlikely to mediate the effect of stores on iron absorption. However, serum ferritin concentration reflects the amount of storage iron present in the body over a wide range from iron deficiency to severe overload, including that in normal subjects (Jacobs, Miller, Worwood, Beamish, and Wardrop, 1972; Walters, Miller, and Worwood, 1973). In addition, there is a marked negative correlation between serum ferritin concentration and iron absorption both in normal subjects and patients with haemochromatosis (Walters, Jacobs, Worwood, Trevett, and Thomson, 1975) The level of circulating ferritin must therefore be considered as a possible regulator of intestinal iron absorption.

The present work was undertaken first to confirm that iron absorption in the rat is related to body iron stores, as has been established in man, and secondly to investigate the effect of raising the serum ferritin concentration by intravenous infusion with homologous ferritin during the absorption process.

Received for publication 9 June 1975.

\section{Materials and Methods}

All experiments were performed on 3-month-old male Wistar rats which were maintained on a standard diet (Pilsbury's Ltd). They were starved for 24 hours before an experiment but were allowed water ad libitum.

\section{EXPERIMENT A：STORAGE IRON SUPPLEMENTATION}

Storage iron was increased by the intramuscular injection of $5 \mathrm{mg}$ of iron in the form of iron-sorbitolcitrate (Jectofer) on alternate days until the required amount had been given. There were five rats in the group given $10 \mathrm{mg}$ iron and six rats in each of the other groups. Rats were given a total of $5,10,20$, 30,40 or $50 \mathrm{mg}$ of iron. They were allowed to equilibrate for 14 days after the last injection before absorption tests were performed. The control group of five rats was not given an iron supplement.

The test solution was administered by stomach tube, under light ether anaesthesia. The solution contained $5 \mu \mathrm{g}$ of $\left[{ }^{59} \mathrm{Fe}\right]$ ferric ammonium sulphate with an activity of $1 \mu \mathrm{Ci}$ made up in $1 \mathrm{ml}$ of $0.05 \mathrm{M}$ $\mathrm{HCl}$. Immediately after administration the radioactivity of the dose was measured by placing the whole rat in a lead-shielded ring of eight matched GeigerMüller tubes coupled to an IDL 1700 scaler. After seven days, the rat was counted again before being killed by exsanguination under ether anaesthesia. 
EXPERIMENT B: INTRAVENOUS FERRITIN INFUSION

Pure ferritin was prepared from rat liver by the method of Aherne and Worwood (1974). The solution for infusion was made up in $0.9 \%$ sterile sodium chloride at a concentration of $100 \mu \mathrm{g}$ ferritin per $\mathrm{ml}$. Anaesthesia was induced by the intraperitoneal injection of $12 \mathrm{mg}$ sodium pentobarbitone (Nembutal) per $100 \mathrm{~g}$ body weight. The jugular vein was exposed and cannulated with an 18 inch long Portex cannula (external diameter $1 \mathrm{~mm}$ ) which was connected to a Palmer slow-infusion pump. The abdomen was opened in the midline, and the tip of a 3 inch long nylon cannula was introduced into the duodenum through an incision in the pyloric region of the stomach. The gut was tied around the cannula with 2/0 Mersilk and a second ligature was placed around the gut at the ileocaecal junction. The abdominal wall was then closed around the intestinal cannula, and the slow infusion pump connected to the jugular cannula was started.

The 14 rats in the control group were perfused with a total of $1.0 \mathrm{ml}$ of $0.9 \%$ sterile sodium chloride solution. The 12 rats in the experimental group received a total of $1.0 \mathrm{ml}$ of $0.9 \%$ sterile sodium chloride solution containing $100 \mu \mathrm{g}$ of rat ferritin. The volume of solution perfused was less than $10 \%$ of the estimated blood volume in each case. The total perfusion time was 45 minutes.

After the perfusion had been running for 15 minutes, $1 \mathrm{ml}$ of the same solution of iron in hydrochloric acid used in experiment $\mathbf{A}$ was introduced into the gut through the intestinal cannula. The rat was killed by exsanguination 30 minutes after the introduction of the test solution, and the entire ligated length of gut was removed. Absorption was estimated as the difference between whole blood activity, ie, carcase, gut and whole heparinized blood, and the activity in the eviscerated body, ie, carcase and whole heparinized blood.

The proportion of administered ${ }^{59} \mathrm{Fe}$ in the whole gut was determined and immediately after this the contents were removed by gently flushing with $90 \mathrm{ml}$ of ice-cold $0.9 \%$ sodium chloride solution. The activity in the washed gut was then measured and the activity in the gut wall calculated.

\section{IRON STATUS}

In all experiments, haemoglobin and packed cell volumes were determined using standard haematological techniques (Dacie and Lewis, 1968). Serum iron and total iron-binding capacity (TIBC) were determined by a modification of the method of Young and Hicks (1965). The amount of non-haem iron in the liver was estimated by a modification of the method of Brückman and Zondek (1940). Ferritin was estimated by a modification of the immunoradiometric assay of Addison, Beamish, Hales, Hodgkins, Jacobs, and Llewellin (1972).

\section{Results}

\section{EFFECT OF STORAGE IRON ON IRON ABSORPTION}

Haemoglobin concentration and packed cell volumes were similar in all groups. Liver non-haem iron concentrations were increased from the control mean of $8 \cdot 3 \pm 1 \cdot 1 \mathrm{mg}$ per $100 \mathrm{~g}$ tissue to a maximum of $74.4 \pm 5.8 \mathrm{mg}$ per $100 \mathrm{~g}$ in the group given $50 \mathrm{mg}$ of iron. Total iron-binding capacities were comparable in all groups, but serum iron levels and transferrin saturations showed a slight increase in a few instances (table I).

There was some evidence of a relationship between the amount of iron injected and the serum iron concentration $(r=0.355 ; P<0.05)$. Trans-

\begin{tabular}{|c|c|c|c|c|c|c|c|}
\hline & \multicolumn{7}{|c|}{ mg of Fe as Jectofer } \\
\hline & 50 & 40 & 30 & 20 & 10 & 5 & 0 \\
\hline Number of rats & 6 & 6 & 6 & 6 & 5 & 6 & 5 \\
\hline $\begin{array}{l}\text { Weight (g) } \\
\mathrm{Hb}(\mathrm{g} / \mathrm{dl}) \\
\operatorname{PCV}(\%)\end{array}$ & $\begin{array}{r}239.5 \pm 10.4 \\
15.8 \pm 0.3 \\
48.7 \pm 0.9\end{array}$ & $\begin{array}{r}246.7 \pm 7.6 \\
16.5 \pm 0.3 \\
50.3 \pm 0.8\end{array}$ & $\begin{array}{r}245 \cdot 8 \pm 9 \cdot 5 \\
17 \cdot 1 \pm 0.3 \\
51 \cdot 3 \pm 0.5\end{array}$ & $\begin{array}{r}244.5 \pm 6.5 \\
16.6 \pm 0.4 \\
51.0 \pm 1.1\end{array}$ & $\begin{array}{r}245 \cdot 2 \pm 10 \cdot 1 \\
16 \cdot 7 \pm 0.2 \\
51 \cdot 0 \pm 0.5\end{array}$ & $\begin{array}{r}284 \cdot 7 \pm 12.8 \\
16.2 \pm 0.4 \\
48.7 \pm 0.3\end{array}$ & $\begin{array}{r}274.0 \pm 10.3 \\
15.4 \pm 0.3 \\
48.0 \pm 0.6\end{array}$ \\
\hline $\begin{array}{l}\text { Serum iron }(\mu \mathrm{mol} / 1) \\
\text { TIBC }(\mu \mathrm{mol} / 1) \\
\text { TS }(\%)\end{array}$ & $\begin{array}{l}29 \cdot 7 \pm 2 \cdot 3^{1} \\
65 \cdot 5 \pm 2 \cdot 9 \\
46 \pm 5\end{array}$ & $\begin{array}{l}30 \cdot 2 \pm 1 \cdot 2^{2} \\
69 \cdot 5 \pm 2 \cdot 1 \\
44 \pm 2^{1}\end{array}$ & $\begin{array}{l}19 \cdot 0 \pm 1 \cdot 1 \\
70 \cdot 3 \pm 3 \cdot 0 \\
28 \pm 3\end{array}$ & $\begin{array}{l}28 \cdot 1 \pm 1 \cdot 1^{1} \\
71 \cdot 1 \pm 3 \cdot 0 \\
40 \pm 2\end{array}$ & $\begin{array}{l}26 \cdot 5 \pm 1 \cdot 8 \\
70 \cdot 9 \pm 3 \cdot 2 \\
37 \pm 1\end{array}$ & $\begin{array}{l}23 \cdot 3 \pm 2 \cdot 0 \\
73 \cdot 6 \pm 2 \cdot 5 \\
32 \pm 2\end{array}$ & $\begin{array}{l}23 \cdot 3 \pm 1 \cdot 6 \\
68 \cdot 7 \pm 2 \cdot 3 \\
34 \pm 3\end{array}$ \\
\hline $\begin{array}{l}\text { Liver non-haem iron } \\
\text { (mg/100 g tissue) }\end{array}$ & $74.4 \pm 5.8$ & $66.1 \pm 1.6$ & $37 \cdot 8 \pm 2 \cdot 3$ & $43.9 \pm 3.6$ & $26.9 \pm 1.4$ & $13.3 \pm 0.5$ & $8 \cdot 3 \pm 1 \cdot 1$ \\
\hline $\begin{array}{l}{ }^{50} \mathrm{Fe} \text { absorption } \\
\text { ( } \% \text { of dose at } 7 \text { days) }\end{array}$ & $4.1 \pm 0.8$ & $17 \cdot 7 \pm 3 \cdot 7$ & $24.3 \pm 3.4$ & $19.4 \pm 3.8$ & $29.1 \pm 3.5$ & $17 \cdot 8 \pm 4.8$ & $41.5 \pm 2.6$ \\
\hline
\end{tabular}

Table I Haematological data and iron absorption in rats with varying iron stores following loading with iron-sorbitol-citrate (mean values $\pm S E$ )

Significance of difference from control group ${ }^{1} \mathrm{P}<0.05>0.02 ;{ }^{2} \mathrm{P}<0.01>0.001$. 
ferrin saturation also showed a correlation with the dose of iron given $(r=0.424 ; \mathrm{P}<0.01)$. However, there was no correlation between serum iron concentration and iron absorption, or between transferrin saturation and iron absorption.

Iron absorption was maximal in the control group of animals with a mean value of $41.5 \pm 2.6 \%$ of the dose given. There was a gradual decrease with increasing concentration of liver non-haem iron, reaching a minimum in animals given $50 \mathrm{mg}$ of iron whose mean absorption was $4.1 \pm 0.8 \%$ (table I). There was a significant negative correlation between liver non-haem iron concentration and iron absorption $(r=0.59 ; \mathrm{P}<0.001)$.

\section{EFFECT OF INCREASED SERUM FERRITIN ON IRON ABSORPTION}

There was no significant difference between the group of rats perfused with saline and those perfused with ferritin with respect to weight, haemoglobin concentration, packed cell volume or liver nonhaem iron concentration (table II). Following the ferritin perfusion there was a hundredfold increase in serum ferritin concentration together with a slight increase in serum iron concentration and transferrin saturation. Despite this considerable change in circulating ferritin concentration there was no difference in iron absorption between the two groups, nor was there any difference in the proportion of the

\begin{tabular}{|c|c|c|c|c|}
\hline & $\begin{array}{l}\text { Saline } \\
\text { Perfusion }\end{array}$ & $\begin{array}{l}\text { Signifi- } \\
\text { cance }\end{array}$ & $\begin{array}{l}\text { Ferritin } \\
\text { Perfusion }\end{array}$ & \\
\hline Number of rats & 14 & & 12 & \\
\hline $\begin{array}{l}\text { Weight (g) } \\
\text { Hb (g/dl) } \\
\text { PCV (\%) }\end{array}$ & $\begin{array}{r}223 \cdot 3 \pm 10 \cdot 1 \\
15 \cdot 3 \pm 0.3 \\
49.0 \pm 1.0\end{array}$ & & $\begin{array}{r}223 \cdot 3 \pm \\
15 \cdot 0 \pm \\
48 \cdot 7 \pm\end{array}$ & $\begin{array}{r}11 \cdot 2 \\
0.3 \\
1.0\end{array}$ \\
\hline Serum iron $(\mu \mathrm{mol} / \mathrm{l})$ & $21.5 \pm 2.8$ & $\begin{array}{l}\text { Not sign } \\
P<0.02\end{array}$ & $30.6 \pm$ & 1.9 \\
\hline TIBC $(\mu \mathrm{mol} / \mathrm{l})$ & $70 \cdot 2 \pm 3.0$ & Not sign & icant $^{73.6 \pm}$ & $2 \cdot 5$ \\
\hline TS (\%) & $31 \cdot 3 \pm 4 \cdot 0$ & $P<0.05$ & $42 \cdot 2 \pm$ & $3 \cdot 1$ \\
\hline $\begin{array}{l}\text { Liver non-haem iron } \\
\text { (mg/100 g tissue) }\end{array}$ & $6 \cdot 1 \pm 0.4$ & Not sign & icant $5 \cdot 4 \pm$ & 0.3 \\
\hline $\begin{array}{l}\text { Serum ferritin } \\
(\mu \mathrm{g} \text { per } 1)\end{array}$ & $139 \cdot 3 \pm 17 \cdot 2$ & Not teste & $13685 \cdot 1 \pm$ & $791 \cdot 6$ \\
\hline $\begin{array}{l}30 \mathrm{Fe} \text { absorption at } \\
30 \mathrm{~min} \text { ( } \% \text { of dose) }\end{array}$ & $12 \cdot 4 \pm 1 \cdot 0$ & Not sign & icant $^{11 \cdot 6 \pm}$ & $1 \cdot 1$ \\
\hline $\begin{array}{l}\text { so } \mathrm{Fo} \text { in gut wall } \\
\% \text { of dose) }\end{array}$ & $23 \cdot 6 \pm 2 \cdot 6$ & Not sign & $28 \cdot 3 \pm$ & 3.4 \\
\hline $\begin{array}{l}{ }^{80} \mathrm{Fe} \text { in gut contents } \\
(\% \text { of dose })\end{array}$ & $63 \cdot 1 \pm 3 \cdot 3$ & Not sign & $60 \cdot 3 \pm$ & $4 \cdot 6$ \\
\hline
\end{tabular}

Table II Haematological data, intestinal iron uptake and iron absorption in rats given an intravenous perfusion of either saline or ferritin (mean values $\pm S E$ ) administered iron taken up by the intestinal mucosa (table II).

\section{Discussion}

In man there is a well documented negative correlation between the amount of iron in stores and the absorption of iron from the gut (Heinrich, 1970; Turnbull, 1974). The present data confirm a similar relationship in the rat. It has long been postulated that a humoral factor may be responsible for regulating iron absorption and there have been a number of reports on this subject (Conrad, 1969). The factor concerned has not been identified.

There is now a considerable body of data indicating that the concentration of circulating ferritin is directly related to iron stores over a very wide range (Jacobs et al, 1972; Lipschitz, Cook, and Finch, 1974; Jacobs and Worwood, 1975). The main exceptions to this are patients with liver disease, leukemia or other malignant or inflammatory diseases (Jacobs and Worwood, 1975). In normal subjects there is a close relationship between mobilizable iron stores measured by a phlebotomy technique and the serum ferritin concentration (Walters $e t$ al, 1973). The estimation of serum ferritin provides a more accurate and quantitative index of body iron stores than the semi-quantitative visual assessment of stainable bone marrow iron (Bentley and Williams, 1974) and it is this technique that has been used to confirm the relationship between iron stores and iron absorption in normal subjects. Walters et al (1975) studied 52 healthy adults with normal haemoglobin concentrations, serum iron concentrations above $70 \mu \mathrm{g}$ per $100 \mathrm{ml}$ and transferrin saturations above $16 \%$. There was no correlation between iron absorption and any of these parameters though there was a significant negative correlation with serum ferritin $(\mathrm{r}=-0.4, \mathrm{P}<0.005)$.

The association between the concentration of circulating ferritin and iron absorption suggests that ferritin might play a regulatory role. It is perhaps also relevant that circulating ferritin appears to have a short life in the plasma with estimates of half-disappearance times varying between four and 40 minutes in the rat (Jacobs and Worwood, 1975). While most of this ferritin is cleared to the liver the destiny of the remainder is unknown.

When we compared absorption in normal rats and in rats whose serum ferritin was increased a hundredfold we found no difference between the two groups. The lack of effect was not due to an unsatisfactory experimental preparation, as absorption in the control group was comparable with that in the intact rat over the same period of time (Worwood and Jacobs, 1971). Evidently, the absorptive capacity 
of the gut was not affected either by the preparatory operation or the perfusion.

It is possible that the perfusion with ferritin was too brief, allowing insufficient time for it to become effective at the target site. However, ferritin injected intravenously has a half-disappearance time measured in minutes suggesting that any effect it might have on intestinal absorption should be quickly apparent. In our experiments, the rat was perfused with ferritin for a total of 45 minutes, which we considered should be sufficient to detect an effect.

In contrast to the human experiments mentioned above, in which there was a significant correlation between serum ferritin and iron absorption, the serum ferritin concentrations in our perfused rats were artificially raised and did not reflect the animals' endogenous iron metabolism. Under these circumstances circulating ferritin concentration is not related to iron absorption. It appears, therefore, that while the amount of storage iron regulates absorption in the rat as well as in man, it does not do so simply through variations in the concentration of circulating ferritin.

\section{References}

Addison, G. M., Beamish, M. R., Hales, C. N., Hodgkins, M., Jacobs, A., and Llewellin, P. (1972). An immunoradiometric assay for ferritin in the serum of normal subjects and patients with iron deficiency and iron overload. J. clin. Path., 25, 326329.

Aherne, W., and Worwood, M. (1974). Some properties of human serum ferritin. Biochem. Soc. Trans., 2, 429-432.
Bentley, D. P., and Williams, P. (1974). Serum ferritin concentration as an index of storage iron in rheumatoid arthritis. J. clin. Path., 27, 786-788.

Bruckmann, G., and Zondek, S. G. (1940). An improved method for the determination of non-hemin iron. J. biol. Chem., 135, 23-30.

Conrad, M. E. (1969). Humoral regulation of iron absorption. Gastroenterology, 57, 225-228.

Conrad, M. E., and Crosby, W. H. (1962). The natural history of iron deficiency induced by phlebotomy. Blood, 20, 173-185.

Dacie, J. V., and Lewis, S. M. (1968). Practical Haematology, 4th ed. Churchill, London.

Heinrich, H. C. (1970). Intestinal iron absorption in man-methods of measurement, dose relationship, diagnostic and therapeutic applications. In Iron Deficiency, edited by L. Hallberg, H. G. Harwerth, and A. Vannotti. Academic Press, New York.

Jacobs, A. (1973). The mechanism of iron absorption. Clin. Haemat., 2, 323-337.

Jacobs, A., Miller, F., Worwood, M., Beamish, M. R., and Wardrop, C. A. (1972). Ferritin in the serum of normal subjects and patients with iron deficiency and iron overload. Brit. med. J., 4, 206-208.

Jacobs, A., and Worwood, M. (1975). Ferritin in serum: clinical and biochemical implications. New Engl. J. Med., 292, 951-956.

Lipschitz, D. A., Cook, J. D., and Finch, C. A. (1974). A clinical evaluation of serum ferritin as an index of iron stores. New Engl. J. Med., 290, 1213-1216.

Pirzio-Biroli, G., and Finch. C. A. (1960). Iron Absorption. III. The influence of iron stores on iron absorption in the normal subject. J. Lab. clin. Med., 55, 216-220.

Turnbull, A. (1974). Iron absorption. In Iron in Biochemistry and Medicine, edited by A. Jacobs and M. Worwood. Academic Press, New York.

Walters, G. O., Miller, F. M., and Worwood, M. (1973). Serum ferritin concentration and iron stores in normal subjects.J.clin. Path., 26, 770-772.

Walters, G. O., Jacobs, A., Worwood, M., Trevett, D., and Thomson, W. (1975). Iron absorption in normal subjects and patients with idiopathic haemochromatosis: relationship with serum ferritin concentration. Gut, 16, 188-192.

Worwood, M., and Jacobs A. (1971). The subcellular distribution of orally administered ${ }^{50} \mathrm{Fe}$ in rat small intestinal mucosa. Brit. J. Haemat., 20, 587-597.

Young, D. S., and Hicks, J. M. (1965). Method for the automatic determination of serum iron. J. clin. Path., 18, 98-102. 